\title{
Influence of coastal groundwater salinization on the distribution and risks of heavy metals
}

\author{
Xiaohu Wen ${ }^{a}$, Jian $\mathrm{Lu}^{\mathrm{b}, *}$, Jun $\mathrm{Wu}^{\mathrm{c}}$, Yichen Lin ${ }^{\mathrm{b}}$, Yongming Luo ${ }^{\mathrm{b}}$

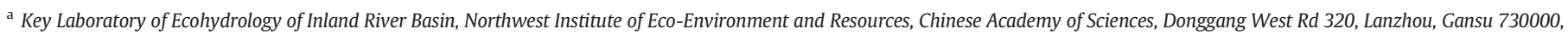 \\ People's Republic of China

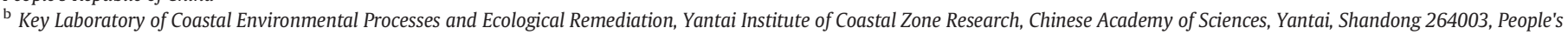 \\ Republic of China \\ c Qinghai Institute of Salt Lakes, Chinese Academy of Sciences, Xining, Qinghai 810008, People's Republic of China
}

\section{H I G H L I G H T S}

- Southwestern coastal plains of study area showed significant groundwater salinization.

- About $13.27 \%$ of sampling sites showed moderate or more serious heavy metal pollution.

- Heavy metals in groundwater exerted low ecological risks.

- Heavy metals in groundwater exerted high cancer risks for adults and children.

- Salinization of coastal groundwater caused the increase in pollution and risks.

\section{A R T I C L E I N F O}

\section{Article history:}

Received 28 July 2018

Received in revised form 18 October 2018

Accepted 18 October 2018

Available online 22 October 2018

Guest Editor: Avelino Nuñez-Delgado

\section{Keywords:}

Coastal groundwater

Heavy metals

Salinization

Pollution

Ecological and health risks

\section{GRAPHICALA B STRACT}

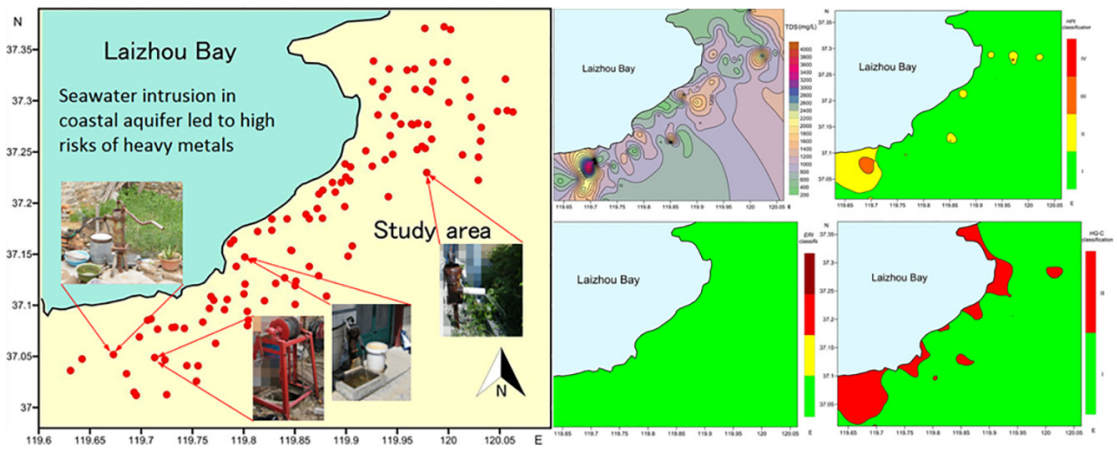

\begin{abstract}
A B S T R A C T
Coastal groundwater quality significantly affects the regional sustainable development, due to the water resource shortage in coastal zone. Current studies on coastal groundwater have mainly focused on saline water intrusion and over-extraction. Information on the heavy metal pollution of coastal groundwater with salinization trend is limited. This study investigated heavy metals in groundwater from a typical coastal region with intensive anthropogenic activities and saline water intrusion. The southwestern coastal plains of the study area showed significant groundwater salinization trend. Heavy metals in the coastal groundwater mainly originated from anthropogenic activities and groundwater salinization according to principal component analysis. Relative high concentrations of $\mathrm{As}, \mathrm{Co}, \mathrm{Cr}, \mathrm{Cu}, \mathrm{Fe}, \mathrm{Mn}$, and $\mathrm{Ni}$ occurred in the southwestern coast of the study area with high TDS level, indicating that the concentrations of these heavy metals in shallow aquifer of the study area might be influenced by the groundwater salinization. Average concentrations of heavy metals in groundwater of the study area ranged from 0.03 (Cd) to $686.92(\mathrm{Fe}$ ) $\mu \mathrm{g} / \mathrm{L}$. Fe was the dominant heavy metal in groundwater with the maximal concentration of $2333.76 \mu \mathrm{g} / \mathrm{L}$ and exceeding-standard rate reaching $98.23 \%$. Approximately $13.27 \%$ of sampling sites showed moderate or higher heavy metal pollution of groundwater based on heavy metal pollution index. Heavy metals in groundwater exerted low ecological risks. Elements $\mathrm{Fe}, \mathrm{Ni}$, and As were the main contributors for ecological risks. Cancer risks of heavy metals for both adults and children were high at all sampling sites. Non-cancer risks for adults and children were unacceptable at $4.42 \%$ and $17.70 \%$ of sampling sites, respectively. The
\end{abstract}

\footnotetext{
* Corresponding author.

E-mail address: jlu@yic.ac.cn (J. Lu).
} 
salinization of the coastal groundwater could also lead to the increase in the ecological and health risks of heavy metals in coastal groundwater. These findings provide initial and important information on heavy metals pollution in coastal aquifer with saline water intrusion.

(c) 2018 Published by Elsevier B.V.

\section{Introduction}

Groundwater is an important type of water resource to play a critical role in the regional development (Béjar-Pizarro et al., 2017; Gholami et al., 2015; Li et al., 2018), especially in areas with limited water resource including coastal regions, arid regions, and megacities (Sefelnasr et al., 2015; Vandenbohede et al., 2009; Zhu et al., 2015). Half of the global megacities are estimated to depend on the groundwater resources for development (Bricker et al., 2017). Groundwater is also important drinking/ domestic water resource in many countries and regions (Béjar-Pizarro et al., 2017; Eschauzier et al., 2013; Fram and Belitz, 2011). Groundwater has attracted wide attention due to various problems caused by overextraction such as land subsidence (Zhu et al., 2015) and seawater/saltwater intrusion (Tam et al., 2014) as well as groundwater quality deterioration such as salinization (Du et al., 2015; Han et al., 2014) and pollution (Santucci et al., 2018; Wen et al., 2018; Wu et al., 2018a).

Groundwater pollution is caused by various substances including nitrogen and phosphorous chemicals (Ağca et al., 2014; Wen et al., 2018; Wu et al., 2018a), heavy metals (Ağca et al., 2014; Chaturvedi et al., 2018), organic pollutants (Eschauzier et al., 2013; Fram and Belitz, 2011; Szekeres et al., 2018), and microbial contaminants (Szekeres et al., 2018). Heavy metals, frequently-detected pollutants in various environmental matrices, attract wide attention due to toxicity, persistence, bioaccumulation, and potential risks to the ecosystems and humans (Burges et al., 2015; Wu et al., 2018b). Therefore, heavy metals in groundwater are a study hotspot (Ağca et al., 2014; Chaturvedi et al., 2018).

Coastal regions usually carry a lot of population to increase water resource demand (Han et al., 2014). Coastal bays are a kind of important geological unit, especially in north China. However, current studies on groundwater from coastal bays of north China focus on salinization and evolution (Du et al., 2015; Han et al., 2014) as well as submarine groundwater discharge (Zhang et al., 2016). Rare information is available on heavy metal pollution of coastal groundwater with salinization trend. The saline water intrusion could change the physical-chemical characteristics of soil, which could subsequently have great influence on the solidwater interface behaviors of heavy metals (Stumm, 1992). Therefore, this study performed field sampling, laboratory analysis, pollution determination, and risk assessment to explore heavy metal pollution and potential ecological-health risks of groundwater in a coastal region with saline water intrusion, severe water shortage and intensive anthropogenic activities. The final aim is to provide initial information on heavy metals pollution in coastal aquifer with saline water intrusion.

\section{Materials and methods}

\subsection{Study area, sampling strategy, and chemical analysis}

Laizhou Bay, a typical coastal bay located in the northern Shandong Peninsula of China, is one of three bays in the Bohai Sea. Due to extremely intensive anthropogenic activities and groundwater overextraction, seawater intrusion in the coastal aquifer of Laizhou Bay coastal area has become the most serious in China (Wen et al., 2018). Laizhou Bay is critical to the sustainable development in coastal regions of Shandong and thus obtains wide investigations (Du et al., 2015; Han et al., 2014). Therefore, this study selected southern Laizhou Bay and shallow groundwater samples were collected from total 113 wells (Fig. 1). The population of the study area was approximately 5 million in 2017 with percentage of non-agricultural population $<15 \%$ according to Shandong Statistical Yearbook. The study area covers gentle hills,
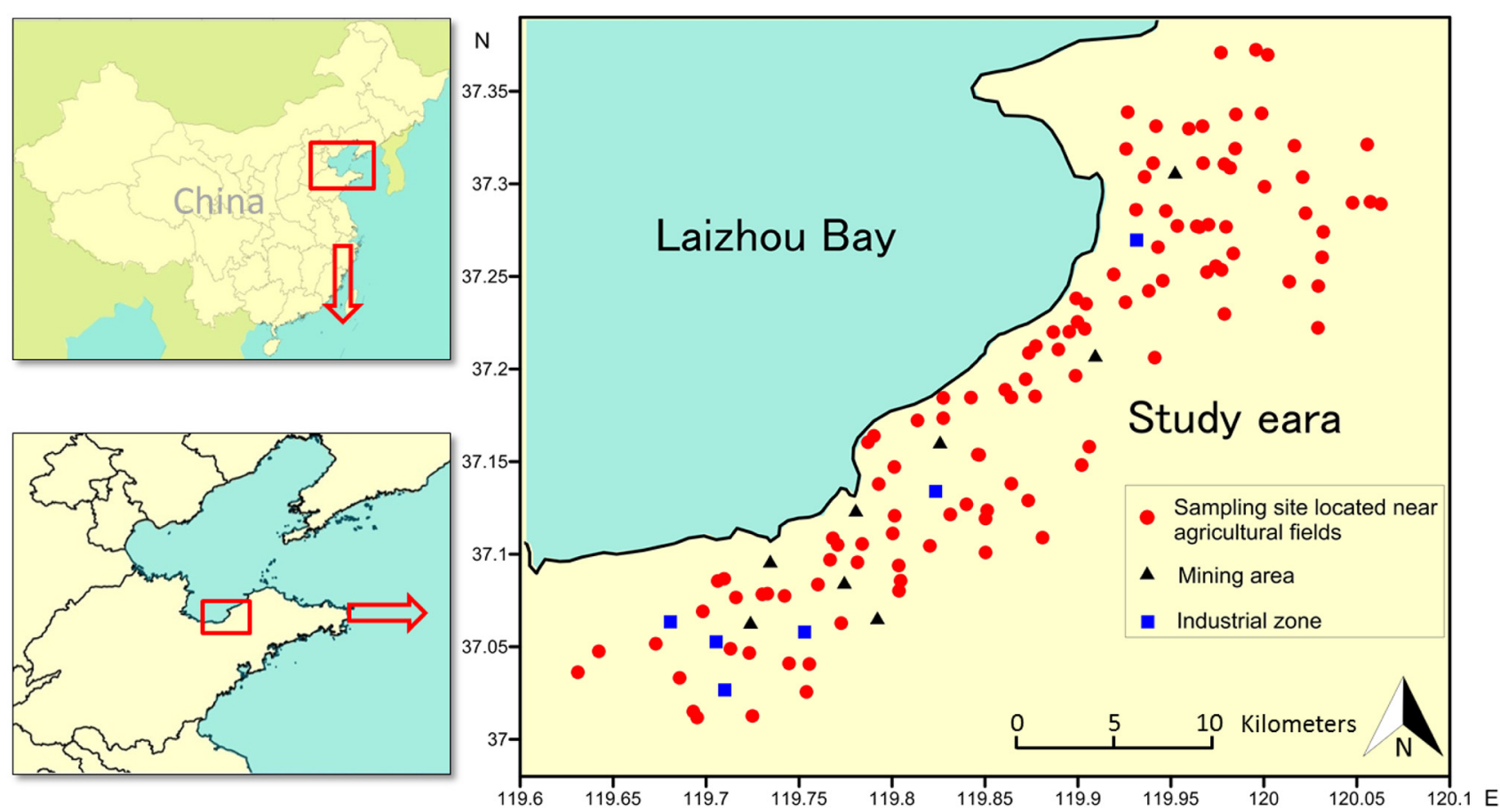

Fig. 1. Study area and the sampling sites of the southern Laizhou Bay. Agricultural fields are located in the surroundings of sampling sites. 
sloping plains, saline-alkali depressions, coastal estuaries, and tidal flats. Lots of villages randomly distribute on the study area so that the quality-centralized water supply is not available for $60 \%$ of residents in the study area. Mining in the study area has been extensively performed for decades. Agriculture is another major anthropogenic activity in the study area so that fertilizers and pesticides are also widely used in this area. Recently, industry is also in development in the study area. Sampling was performed from May to October 2013. All wells, located at the yards of the residents to collect shallow groundwater, provided daily drinking water as well as shower water for them. The water quality was not further controlled. The depth of shallow aquifers that were mainly made up of fine sands, medium-fine sands, and sand loams ranged from 2 to $30 \mathrm{~m}$ (Fig. S1). Each groundwater sample with 500 $\mathrm{mL}$ volume was stored in a pre-cleaned armor glass bottle and transported back to the laboratory as soon as possible. The groundwater samples were filtered through $0.45 \mu \mathrm{m}$ membrane filters (Pall Life Sciences, Ann Arbor, MI, USA) and stored at $4{ }^{\circ} \mathrm{C}$ until analysis.

Total dissolved solids (TDS), $\mathrm{pH}$, and electrical conductivity (EC) of each groundwater sample were in situ monitored using an Ultrameter II ${ }^{\mathrm{TM}}$ 6P (Myron L Company, USA). Concentrations of 10 typical heavy metals in groundwater samples including arsenic (As), cadmium (Cd), chromium $(\mathrm{Cr})$, cobalt $(\mathrm{Co})$, copper $(\mathrm{Cu})$, iron $(\mathrm{Fe})$, lead $(\mathrm{Pb})$, manganese $(\mathrm{Mn})$, nickel $(\mathrm{Ni})$, and zinc ( $\mathrm{Zn})$ were determined by an ELAN DRC II inductively coupled plasma mass spectrometry (ICP-MS, PerkinElmer Ltd., MA, USA). Limits of detection (LOD) and limits of quantity (LOQ) of target heavy metals in coastal groundwater were shown in Table S1. Method blank (Millipore ultrapure water), spiked blank (Millipore ultrapure water spiked by mixture solution of target heavy metals), and spiked sample (one real groundwater sample spiked by mixture solution of target heavy metals) were analyzed in duplicate for every 10 real groundwater samples to assure quality control of analysis. Recoveries of target heavy metals were in the range of $89.5 \%$ $107.2 \%$ for spiked blanks and in the range of $87.6 \%-109.6 \%$ for spiked samples.

\subsection{Heavy metal pollution of groundwater}

Three methods including heavy metal pollution index (HPI), the Nemerow index $(N I)$, and contamination degree $(C D)$ were employed to determine groundwater heavy metal pollution of southern Laizhou Bay. The most serious evaluation results would be used to exhibit the final pollution status based on the worst scenario.
HPI was calculated by the following equation (Qu et al., 2018):

$$
H P I=\frac{\sum_{i=1}^{n}\left(\frac{M C_{i}}{S C_{i}} \times 100\right) \times\left(\frac{1}{S C_{i}}\right)}{\sum_{i=1}^{n} \frac{1}{S C_{i}}}
$$

where $S C_{i}$ and $M C_{i}$ refer to assessment standard concentration $(\mu \mathrm{g} / \mathrm{L})$ and the measured concentration $(\mu \mathrm{g} / \mathrm{L})$ of the target heavy metal in groundwater; $n$ represents the numbers of target heavy metals. $S C_{i}$ value of target heavy metal was set as Class III concentration threshold of "Standard for groundwater quality (GB/T 14848-2017)". Pollution ranking criteria of HPI referred to Table 1.

The following equation showed how NI was calculated (Liu et al., 2015a; Vu et al., 2017):

$N I=\sqrt{\frac{\left(\frac{M C_{i}}{S C_{i}}\right)_{\text {mean }}^{2}+\left(\frac{M C_{i}}{S C_{i}}\right)_{\max }^{2}}{2}}$

where $\left(\frac{M C_{i}}{S C_{i}}\right)_{\max }$ and $\left(\frac{M C_{i}}{S C_{i}}\right)_{\text {mean }}$ refer to the maximal value and average value of $\left(\frac{M C_{i}}{S C_{i}}\right)$ among all target heavy metals. Pollution evaluation criteria based on $N I$ referred to Table 1.

$C D$ was calculated according to the following equation (Sharifi et al., 2016):

$C D=\sum_{i=1}^{n} \frac{M C_{i}}{S C_{i}}$

Table 1 also provided the pollution evaluation criterion of $C D$.

\subsection{Ecological risks of heavy metals in groundwater}

Ecological risk index (ERI) model was employed to evaluate the potential ecological risks posed by heavy metals in groundwater of the study area (Sharifi et al., 2016):

$E R I=\sum_{i=1}^{n} T_{i} \times \frac{M C_{i}}{S C_{i}}$

where $T_{i}$ is the biological toxicity factor of a target heavy metal. The values of $T_{i}$ for all target heavy metals were selected from the literatures

Table 1

Ranking criteria of pollution, ecological risk, and cancer risk.

\begin{tabular}{|c|c|c|c|c|}
\hline Method & Pollution or risk level & Classification & Value & References \\
\hline \multirow[t]{4}{*}{ Heavy metal pollution index $(H P I)$} & Low pollution & I & $H P I<15$ & \multirow[t]{4}{*}{ Edet and Offiong, 2002; Qu et al., 2018} \\
\hline & Moderate pollution & II & $15 \leq H P I \leq 30$ & \\
\hline & Moderate-to-heavy pollution & III & $30<H P I \leq 100$ & \\
\hline & Heavy pollution & IV & $H P I>100$ & \\
\hline \multirow[t]{4}{*}{ Nemerow index $(N I)$} & Insignificant pollution & I & $N I<1$ & \multirow[t]{4}{*}{ Liu et al., 2015a; Vu et al., 2017} \\
\hline & Slight pollution & II & $1 \leq N I<2.5$ & \\
\hline & Moderate pollution & III & $2.5 \leq N I<7$ & \\
\hline & Heavy pollution & IV & $N I \geq 7$ & \\
\hline \multirow[t]{4}{*}{ Contamination degree $(C D)$} & Low pollution & I & $C D<6$ & \multirow[t]{4}{*}{ Sharifi et al., 2016} \\
\hline & Moderate pollution & II & $6 \leq C D<12$ & \\
\hline & Considerable pollution & III & $12 \leq C D<24$ & \\
\hline & Very heavy pollution & IV & $C D \geq 24$ & \\
\hline \multirow[t]{4}{*}{ Ecological risk index $(E R I)$} & Low risk & I & $E R I<110$ & \multirow[t]{4}{*}{ Sharifi et al., 2016} \\
\hline & Moderate risk & II & $110 \leq E R I<200$ & \\
\hline & Considerable risk & III & $200 \leq E R I<400$ & \\
\hline & Very high risk & IV & $E R I \geq 400$ & \\
\hline \multirow[t]{5}{*}{ Cancer risk $(C R)$} & Very low risk & I & $\mathrm{CR} \leq 1 \times 10^{-6}$ & \multirow[t]{5}{*}{ Ge et al., 2013} \\
\hline & Low risk & II & $1 \times 10^{-6}<\mathrm{CR} \leq 1 \times 10^{-4}$ & \\
\hline & Moderate risk & III & $1 \times 10^{-4}<\mathrm{CR} \leq 1 \times 10^{-3}$ & \\
\hline & High risk & IV & $1 \times 10^{-3}<\mathrm{CR} \leq 0.1$ & \\
\hline & Very high risk & V & $\mathrm{CR}>0.1$ & \\
\hline
\end{tabular}


(Hakanson, 1980; Sharifi et al., 2016). Ecological risk levels were determined based on the ranking criteria (Table 1 ).

\subsection{Health risks of heavy metals in groundwater}

Heavy metals in groundwater exert health risks through ingestion (drinking water) and dermal contact (such as shower). The health risks are evaluated using cancer risks $(C R)$ and hazard quotients $(H Q)$.

Health risks through ingestion pathway posed by heavy metals in groundwater of the study area were calculated by the following equations (Liu et al., 2015b; USEPA, 2016):

$C R_{\text {ingestion }}($ individual $)=\frac{M C_{i} \times D R \times E F_{i} \times E D_{i}}{B W \times A T} \times S F$

$H Q_{\text {ingestion }}($ individual $)=\frac{M C_{i} \times D R \times E F_{i} \times E D_{i}}{B W \times A T \times R f D}$

$C R_{\text {ingestion }}=\sum C R_{\text {ingestion }}($ individual $)$

$H Q_{\text {ingestion }}=\sum H Q_{\text {ingestion }}($ individual $)$

where $D R$ means water consumption rate; $E F_{i}$ means ingestion exposure frequency; $E D_{i}$ refers to ingestion exposure duration; $B W$ refers to body weight; $A T$ means average lifespan; $S F$ refers to cancer slope factor; RfD refers to the reference dose of the chemical through oral exposure route. The values of $S F$ and RfD could be obtained from the USEPA guidelines (USEPA, 2016). The values of other parameters referred to Wu et al. (2016). The values of parameters were briefly shown in Table S2.

Health risks through dermal contact were calculated by the following equations (USEPA, 2004):

$$
\begin{aligned}
C R_{\text {dermal }}(\text { individual })= & K_{P} \times M C_{i} \times t_{\text {event }} \times \frac{E V \times E D_{d} \times E F_{d} \times S A}{B W \times A T} \times \frac{S F}{G I A B S} \\
H Q_{\text {dermal }}(\text { individual })= & K_{P} \times M C_{i} \times t_{\text {event }} \times \frac{E V \times E D_{d} \times E F_{d} \times S A}{B W \times A T} \\
& \times \frac{1}{R f D \times G I A B S}
\end{aligned}
$$

$C R_{\text {dermal }}=\sum C R_{\text {dermal }}$ (individual $)$

$H Q_{\text {dermal }}=\sum H Q_{\text {dermal }}($ individual $)$

where $K_{\mathrm{P}}$ refers to dermal permeability coefficient of pollutant; $t_{\text {event }}$ represents event duration; $E D_{d}, E V$, and $E F_{d}$ represent dermal contact exposure duration, the event frequency, and dermal contact exposure frequency, respectively; GIABS is the fraction of chemical absorbed in gastrointestinal tract; $S A$ refers to skin surface area. The values of parameters were obtained from the references and shown in Table S2 (Akhbarizadeh et al., 2016; IRIS, 2018; Ranjbar Jafarabadi et al., 2017; Sarria-Villa et al., 2016; USEPA, 2004; USEPA, 2016).

Health risks posed by heavy metals in groundwater were calculated by the following equations:

$C R=C R_{\text {ingestion }}+C R_{\text {dermal }}$

$H Q=H Q_{\text {ingestion }}+H Q_{\text {dermal }}$

Cancer risk ranking criteria were listed by Table 1. Inadmissible noncancer risk threshold was set to 1 (Qu et al., 2018).

\subsection{Data processing}

All data of concentrations, pollution, ecological risks, and health risks were processed using Surfer 11 (Golden Software LLC, Colorado, USA) to obtain the corresponding distribution/contour maps. The relationship among TDS, pH, and heavy metals in groundwater was determined using the Pearson correlation coefficients calculated by SPSS 19.0 (IBM, New York, USA). Principal component analysis (PCA) was also performed by SPSS 19.0.

\section{Results and discussion}

\subsection{Distribution of $p H, T D S$, and heavy metals in the coastal groundwater}

Distribution of $\mathrm{pH}$ and TDS was shown in Fig. 2. Except 6 wells with $\mathrm{pH}$ ranging from 6.80 to 6.96 , groundwater of the remaining sites exhibited neutral to alkaline with pH varying from 7.00 to 8.63 (Table S3). In general, $\mathrm{pH}$ of groundwater showed site-specific feature that weak acidic groundwater mainly existed in the southwestern part of the study area. Interestingly, TDS concentrations of groundwater in this area were the highest in contrast to those in the rest of regions (Fig. 2). Concentrations of TDS ranged from 246.79 to $3858.02 \mathrm{mg} / \mathrm{L}$ with the average value of $972.27 \mathrm{mg} / \mathrm{L}$ (Table S3). Groundwater type at approximately $59.29 \%$ of sampling sites was fresh water (TDS $<1000 \mathrm{mg} / \mathrm{L}$ ) according to classification criterion (Liu et al., 2017) and groundwater quality at these sites was classified into Class III representing that groundwater was suitable for drinking based on "Standard for groundwater quality (GB/T 14848-2017)". In contrast, groundwater type at approximately $38.94 \%$ of sampling sites was brackish water $(1000<$ TDS $\leq 3000 \mathrm{mg} / \mathrm{L})$ while that at about $1.77 \%$ of sampling sites with shallow aquifer depth of 2-8 $\mathrm{m}$ was saline water $(3000<$ TDS $\leq 50,000 \mathrm{mg} / \mathrm{L})$. Based on the ranking criteria of "Standard for groundwater quality (GB/T 14848-2017)", groundwater quality at about $35.40 \%$ and $5.31 \%$ of sampling sites was classified into Class IV $(1000<$ TDS $\leq 2000 \mathrm{mg} / \mathrm{L})$ representing that groundwater was suitable for drinking after treatment and Class V (TDS $>2000 \mathrm{mg} / \mathrm{L}$ ) representing that groundwater was not suitable for drinking. The southwestern coastal plains of the study area showed significant groundwater salinization trend, similar to the previous reports (Du et al., 2015; Han et al., 2014). EC values ranged from 490.00 to $6332.00 \mu \mathrm{S} / \mathrm{cm}$ with the average value of $1673.06 \mu \mathrm{S} / \mathrm{cm}$ (Fig. S2 and Table S3). Distribution of groundwater EC exhibited the similar variation patterns of TDS.

Concentrations of heavy metals in groundwater of the southern Laizhou Bay ranged from BDL (below detection limit, As at 1 site, Cd at 2 sites, and $\mathrm{Cr}$ at two sites) to $2333.76(\mathrm{Fe}) \mu \mathrm{g} / \mathrm{L}$ with the mean values varying from $0.03(\mathrm{Cd})$ to 686.92 (Fe) $\mu \mathrm{g} / \mathrm{L}$ (Fig. 2 and Table S3). The maximal and average concentrations of $\mathrm{As} / \mathrm{Cd} / \mathrm{Cr}$ in groundwater were 7.63/0.26/37.43 and 1.56/0.03/6.27 $\mu \mathrm{g} / \mathrm{L}$, respectively (Table S3). Concentrations of As, $\mathrm{Cd}$, and $\mathrm{Cr}$ were all below the corresponding Class III thresholds of "Standard for groundwater quality (GB/T 14848-2017)". Concentrations of $\mathrm{Pb}$ and $\mathrm{Co}$ were in the range of 0.06-14.52 and $0.12-3.41 \mu \mathrm{g} / \mathrm{L}$ with the similar average values of 0.65 and $0.52 \mu \mathrm{g} / \mathrm{L}$, respectively, all below the Class III thresholds (Table S3). Concentrations of $\mathrm{Ni}$ ranged from 2.05 to $32.12 \mu \mathrm{g} / \mathrm{L}$ while those of $\mathrm{Zn}$ were in the range of $0.35-195.30 \mu \mathrm{g} / \mathrm{L}$ (Table S3). The average concentrations of $\mathrm{Ni}$ and $\mathrm{Zn}$ were 8.03 and $17.16 \mu \mathrm{g} / \mathrm{L}$, respectively. $\mathrm{Cu}$ and $\mathrm{Mn}$ showed the similar concentration distribution that the concentrations were in the ranges of $0.22-6.04$ (mean: 1.15 ) $\mu \mathrm{g} / \mathrm{L}$ for Cu and 0.11-8.73 (mean: 1.03) $\mu \mathrm{g} / \mathrm{L}$ for $\mathrm{Mn}$ (Table S3). Cu, Fe, Mn, and Zn are essential elements for humans. World Health Organization (WHO) provides provisional guideline values for $\mathrm{Cu}(2000 \mu \mathrm{g} / \mathrm{L})$, Fe $(2000 \mu \mathrm{g} / \mathrm{L})$, Mn $(400 \mu \mathrm{g} / \mathrm{L})$, and $\mathrm{Zn}(3000 \mu \mathrm{g} / \mathrm{L})$ in drinking water (WHO, 2017). However, more strict thresholds for these metals in groundwater of China are provided in "Standard for groundwater quality (GB/T 14848-2017)" to evaluate the groundwater quality by classifying groundwater quality into 5 levels. Groundwater with Class I, II, or III is suitable for drinking while it with Class IV or V is not suitable for drinking. Therefore, "Standard for groundwater quality (GB/T 14848-2017)" was used to evaluate the groundwater quality of the study area. Concentrations of $\mathrm{Pb}, \mathrm{Co}, \mathrm{Cu}$, $\mathrm{Zn}$, and $\mathrm{Mn}$ in groundwater were all below the corresponding Class III thresholds of "Standard for groundwater quality (GB/T 14848-2017)" 

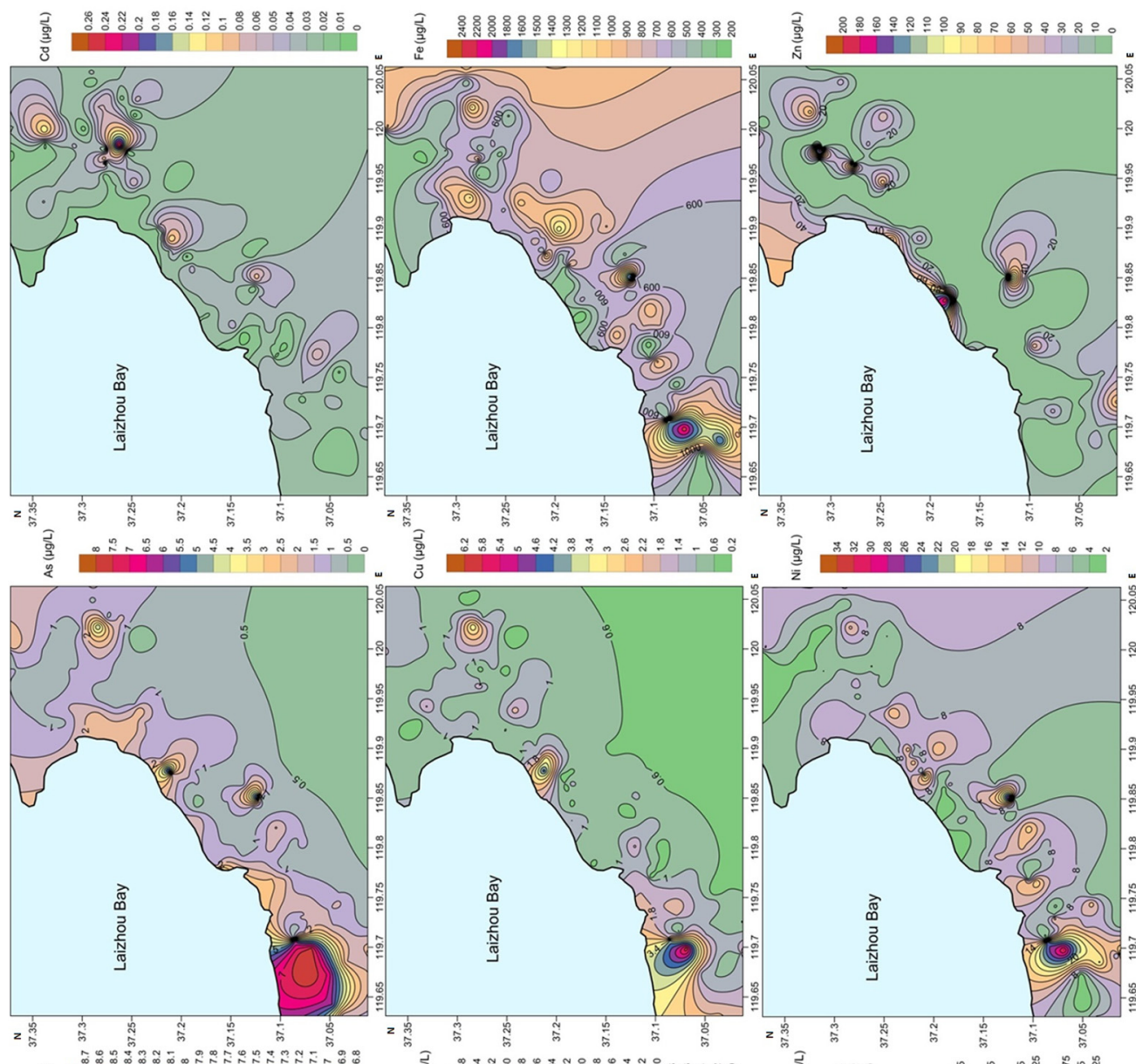

돈
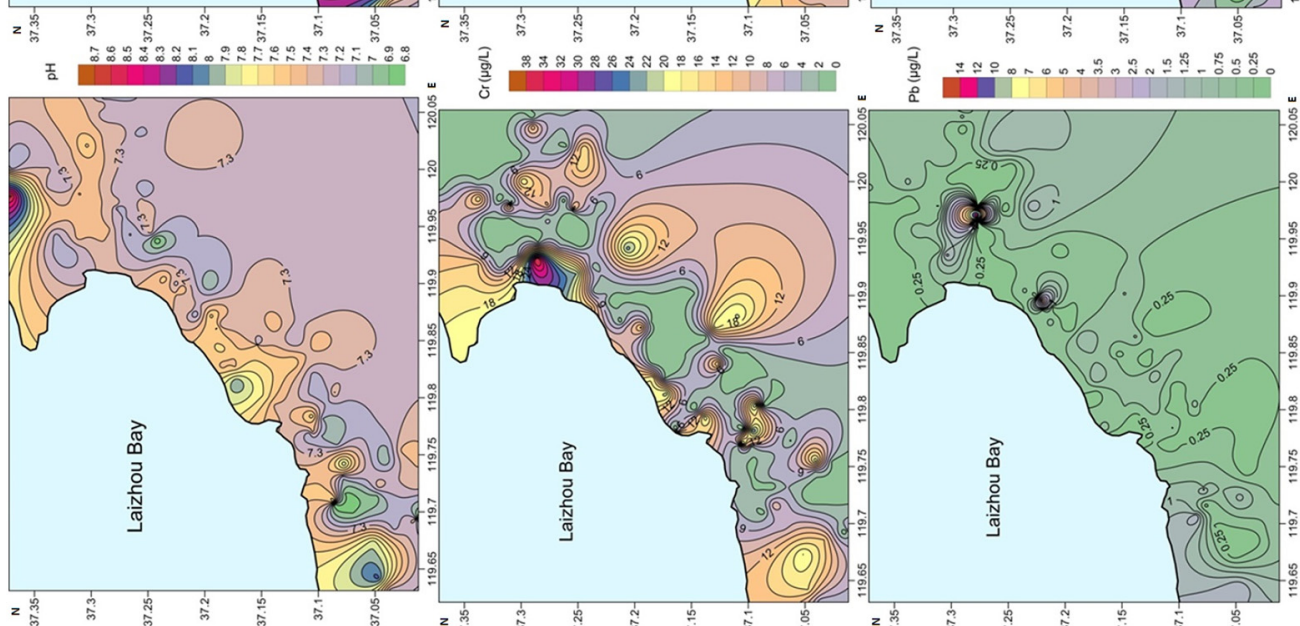

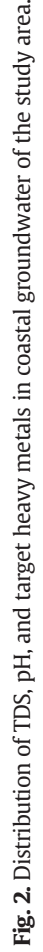
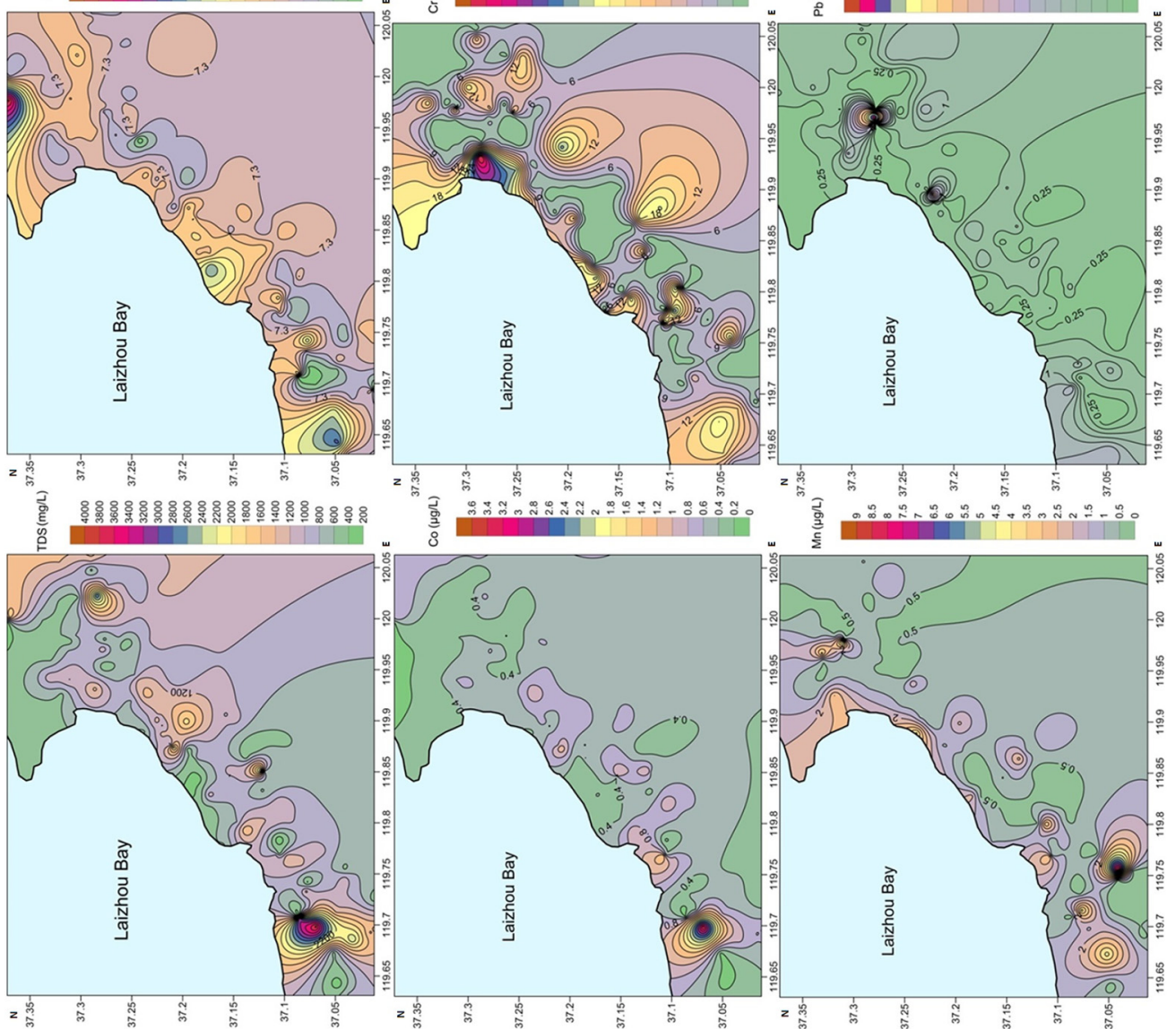
Table 2

Pearson correlation matrix of TDS, pH, EC, and heavy metals in coastal groundwater.

\begin{tabular}{|c|c|c|c|c|c|c|c|c|c|c|c|c|c|}
\hline & $\mathrm{Pb}$ & $\mathrm{Cr}$ & Co & $\mathrm{Ni}$ & $\mathrm{Cu}$ & $\mathrm{Zn}$ & As & $\mathrm{Cd}$ & $\mathrm{Fe}$ & $\mathrm{Mn}$ & TDS & $\mathrm{pH}$ & $\mathrm{EC}$ \\
\hline $\mathrm{Pb}$ & 1.000 & & & & & & & & & & & & \\
\hline $\mathrm{Cr}$ & -0.171 & 1.000 & & & & & & & & & & & \\
\hline Co & 0.001 & -0.096 & 1.000 & & & & & & & & & & \\
\hline $\mathrm{Ni}$ & 0.004 & -0.152 & $0.823^{* *}$ & 1.000 & & & & & & & & & \\
\hline $\mathrm{Cu}$ & 0.045 & -0.169 & $0.618^{* *}$ & $0.537^{* *}$ & 1.000 & & & & & & & & \\
\hline $\mathrm{Zn}$ & -0.076 & $0.200^{*}$ & -0.180 & $-0.208^{*}$ & -0.029 & 1.000 & & & & & & & \\
\hline As & -0.005 & 0.135 & $0.514^{* *}$ & $0.536^{* *}$ & $0.659^{* *}$ & -0.114 & 1.000 & & & & & & \\
\hline $\mathrm{Cd}$ & $0.238^{*}$ & $-0.339^{* *}$ & 0.057 & 0.093 & 0.167 & 0.061 & 0.010 & 1.000 & & & & & \\
\hline $\mathrm{Fe}$ & 0.087 & -0.119 & $0.785^{* *}$ & $0.894^{* *}$ & $0.448^{* *}$ & $-0.212^{*}$ & $0.484^{* *}$ & 0.148 & 1.000 & & & & \\
\hline Mn & -0.097 & $0.269^{* *}$ & 0.012 & 0.001 & -0.022 & $0.240^{*}$ & 0.110 & -0.170 & -0.054 & 1.000 & & & \\
\hline TDS & 0.043 & -0.115 & $0.801^{* *}$ & $0.887^{* *}$ & $0.610^{* *}$ & $-0.222^{*}$ & $0.551^{* *}$ & 0.122 & $0.930^{* *}$ & -0.062 & 1.000 & & \\
\hline $\mathrm{pH}$ & 0.053 & 0.036 & $-0.441^{* *}$ & $-0.562^{* *}$ & $-0.203^{*}$ & 0.072 & -0.049 & -0.072 & $-0.484^{* *}$ & -0.072 & $-0.497^{* *}$ & 1.000 & \\
\hline EC & -0.042 & 0.134 & $0.766^{* *}$ & $0.867^{* *}$ & $0.534^{* *}$ & -0.147 & $0.575^{* *}$ & -0.024 & $0.844^{* *}$ & 0.099 & $0.895^{* *}$ & $-0.535^{* *}$ & 1.000 \\
\hline
\end{tabular}

Note: symbols ${ }^{*}$ and ${ }^{* *}$ mean the significant level at $p<0.05$ and $p<0.01$, respectively.

at all sampling sites. Concentrations of $\mathrm{Ni}$ in groundwater at 3 sites exceeded the Class III threshold $(20 \mu \mathrm{g} / \mathrm{L})$ and those at the remaining sites were below the threshold. Interestingly, concentrations of Fe in groundwater were larger than Class III threshold (300 $\mu \mathrm{g} / \mathrm{L})$ of "Standard for groundwater quality (GB/T 14848-2017)" at $98.23 \%$ of sampling sites, suggesting that Fe pollution of groundwater occurred in the study area. Mining activities in the study area are frequently performed to cause transport of iron into groundwater. Industrial sewage and agricultural activities such as fertilizer usage are also important sources of iron pollution in the groundwater. Concentrations of heavy metals in fresh groundwater, brackish groundwater, and saline groundwater showed different variations. Concentrations of heavy metals in fresh groundwater of the southern Laizhou Bay ranged from $\mathrm{BDL}(\mathrm{Cr})$ to 915.00 (Fe) $\mu \mathrm{g} / \mathrm{L}$ with the average values varying from 0.03 (Cd) to 496.13 (Fe) $\mu \mathrm{g} / \mathrm{L}$. Concentrations of heavy metals in brackish groundwater of the southern Laizhou Bay ranged from BDL $(\mathrm{Cr}, \mathrm{Cd}$, and $\mathrm{As})$ to $1879.90(\mathrm{Fe}) \mu \mathrm{g} / \mathrm{L}$ with the average values varying from $0.04(\mathrm{Cd})$ to 920.80 (Fe) $\mu \mathrm{g} / \mathrm{L}$. Concentrations of heavy metals in saline groundwater of the southern Laizhou Bay ranged from 0.03 (Cd) to 2333.76 (Fe) $\mu \mathrm{g} / \mathrm{L}$ with the average values varying from $0.03(\mathrm{Cd})$ to $1933.16(\mathrm{Fe}) \mu \mathrm{g} / \mathrm{L}$. Distribution of heavy metals in groundwater also showed significant site-specific and chemical-specific features (Fig. 2). The salinity could increase the aqueous concentrations of some heavy metals in soilwater systems (Lu et al., 2004). The salinity could also increase the mobility of heavy metals in the soil (Acosta et al., 2011). Seawater intrusion or salinization was reported to account for increased concentrations of heavy metals in groundwater (Basahi et al., 2018; Kampouroglou and Economou-Eliopoulos, 2017). The highest concentrations of $\mathrm{As}, \mathrm{Co}, \mathrm{Cu}$, $\mathrm{Fe}$, and Ni occurred in the southwestern coast of the study area, similar to TDS, indicating that the concentrations of these heavy metals in shallow aquifer of the study area might be possibly influenced by the groundwater salinization mainly caused by seawater intrusion. This was also proved by the high concentrations of As $(73.34-73.87 \mu \mathrm{g} / \mathrm{L})$, Co (1.06-1.36 $\mu \mathrm{g} / \mathrm{L}), \mathrm{Cu}(128.39-210.08 \mu \mathrm{g} / \mathrm{L})$, Fe (2020.00-3940.00 $\mu \mathrm{g} / \mathrm{L})$, and $\mathrm{Ni}(13.25-19.21 \mu \mathrm{g} / \mathrm{L})$ in 3 seawater samples simultaneously collected from the southwestern coast of the study area. Moreover, some research results further exhibited that increased concentrations of heavy metals in groundwater were attributed to seawater intrusion or salinization (Basahi et al., 2018; Kampouroglou and EconomouEliopoulos, 2017). The highest concentrations of $\mathrm{Cr}$ occurred along the coastline of the northeastern study area while those of Mn occurred in the southern inland part of the study area. However, relatively high concentrations of $\mathrm{Cr}$ and $\mathrm{Mn}$ were also found in the southwestern coast of the study area, similar to TDS. The highest concentrations of Zn occurred in the central part of the study area while those of $\mathrm{Cd}$ and $\mathrm{Pb}$ occurred in the central part of the northeastern study area. The distribution of heavy metals in groundwater suggested that the complex factors including groundwater salinization and anthropogenic activities might influence these chemicals in shallow aquifer of the study area.

Groundwater hydrochemical type in the study area mainly included $\mathrm{HCO}_{3}-\mathrm{Cl}-\mathrm{Ca}, \mathrm{HCO}_{3}-\mathrm{NO}_{3}-\mathrm{Ca}, \mathrm{SO}_{4}-\mathrm{HCO}_{3}-\mathrm{Cl}-\mathrm{Ca}, \mathrm{SO}_{4}-\mathrm{HCO}_{3}-\mathrm{Na}-\mathrm{Ca}, \mathrm{HCO}_{3}-\mathrm{Ca}$, $\mathrm{Cl}-\mathrm{Ca}, \mathrm{HCO}_{3}-\mathrm{Cl}-\mathrm{Na}-\mathrm{Ca}, \mathrm{HCO}_{3}-\mathrm{NO}_{3}-\mathrm{Cl}-\mathrm{Ca}, \mathrm{SO}_{4}-\mathrm{Cl}-\mathrm{Na}-\mathrm{Ca}$, and $\mathrm{HCO}_{3}-\mathrm{Cl}-\mathrm{Ca}$ with the major cation of $\mathrm{Ca}^{2+}$ and major anions of $\mathrm{HCO}_{3}^{-}$and $\mathrm{Cl}^{-}$. Groundwater with low concentrations of heavy metals generally exhibited hydrochemical types of $\mathrm{SO}_{4}-\mathrm{HCO}_{3}-\mathrm{Cl}-\mathrm{Ca}, \mathrm{SO}_{4}-\mathrm{HCO}_{3}-\mathrm{Na}-\mathrm{Ca}$, and $\mathrm{HCO}_{3}-\mathrm{Ca}$ while groundwater with high concentrations of heavy metals usually showed hydrochemical types of $\mathrm{SO}_{4}-\mathrm{Cl}-\mathrm{Na}-\mathrm{Ca}, \mathrm{Cl}-\mathrm{Ca}$, and $\mathrm{HCO}_{3}-\mathrm{Cl}-\mathrm{Ca}$.

\subsection{Possible sources of heavy metals in the coastal groundwater}

Correlation analysis on TDS, pH, EC, and heavy metals in groundwater was shown in Table 2. Significantly positive correlation existed in $\mathrm{Pb}-\mathrm{Cd}$, $\mathrm{Zn}-\mathrm{Mn}$, and $\mathrm{Cr}-\mathrm{Zn}$ at $p<0.05$ as well as in $\mathrm{Cr}-\mathrm{Mn}, \mathrm{Cu}-\mathrm{As}$, Cu-Fe, and As$\mathrm{Fe}$ at $p<0.01$. Co was positively correlated with $\mathrm{Ni}, \mathrm{Cu}, \mathrm{As}$, and $\mathrm{Fe}$ at significance level of $p<0.01$ while Ni was positively correlated with $\mathrm{Cu}, \mathrm{As}$, and $\mathrm{Fe}$ at $p<0.01$. Significantly negative correlation existed in $\mathrm{Cr}-\mathrm{Cd}$ at $p<0.01$ and Zn-Fe at $p<0.05$. TDS was significantly positively correlated with $\mathrm{Co}, \mathrm{Ni}, \mathrm{Cu}, \mathrm{As}$, and $\mathrm{Fe}$ at $p<0.01$ while it was negatively correlated

Table 3

Total variance explained and component matrix for heavy metals in coastal groundwater.

\begin{tabular}{|c|c|c|c|c|c|c|c|}
\hline \multirow[t]{2}{*}{ Component } & \multicolumn{3}{|c|}{ Initial eigenvalues } & \multirow[t]{2}{*}{ Elements } & \multicolumn{3}{|c|}{ Component } \\
\hline & Total & $\%$ of variance & Cumulative \% & & 1 & 2 & 3 \\
\hline 1 & 3.630 & 36.304 & 36.304 & $\mathrm{~Pb}$ & 0.080 & -0.482 & 0.313 \\
\hline 2 & 1.729 & 17.287 & 53.590 & $\mathrm{Cr}$ & -0.190 & 0.732 & -0.018 \\
\hline 3 & 1.156 & 11.565 & 65.155 & Co & 0.894 & 0.104 & -0.053 \\
\hline 4 & 0.883 & 8.830 & 73.985 & $\mathrm{Ni}$ & 0.915 & 0.054 & -0.082 \\
\hline 5 & 0.780 & 7.800 & 81.785 & $\mathrm{Cu}$ & 0.753 & 0.047 & 0.255 \\
\hline 6 & 0.686 & 6.861 & 88.647 & $\mathrm{Zn}$ & -0.260 & 0.319 & 0.730 \\
\hline 7 & 0.583 & 5.835 & 94.481 & As & 0.712 & 0.323 & 0.106 \\
\hline 8 & 0.304 & 3.041 & 97.523 & $\mathrm{Cd}$ & 0.181 & -0.589 & 0.556 \\
\hline 9 & 0.157 & 1.567 & 99.089 & $\mathrm{Fe}$ & 0.880 & -0.013 & -0.076 \\
\hline 10 & 0.091 & 0.911 & 100.00 & $\mathrm{Mn}$ & -0.048 & 0.627 & 0.353 \\
\hline
\end{tabular}


with Zn at $p<0.05$. Similar with TDS, EC was significantly positively correlated with $\mathrm{Co}, \mathrm{Ni}, \mathrm{Cu}, \mathrm{As}$, and $\mathrm{Fe}$ at $p<0.01$. Moreover, EC was also significantly positively correlated with TDS and negatively correlated with $\mathrm{pH}$ at $p<0.01$. In contrast, $\mathrm{pH}$ was only negatively correlated with $\mathrm{Co}$, $\mathrm{Ni}, \mathrm{Cu}, \mathrm{Fe}$, and TDS. These results showed that $\mathrm{Co}, \mathrm{Ni}, \mathrm{Cu}, \mathrm{As}$, and $\mathrm{Fe}$ might be influenced by the same factors or originate from the same/similar sources.

PCA was performed to explore the possible sources of heavy metals in groundwater. Three components with the eigenvalues $>1.0$ were obtained to explain $65.155 \%$ of the total variance (Table 3 ). The first principal component accounting for the largest variance of 36.304\% was mainly composed of the elements $\mathrm{Co}, \mathrm{Ni}, \mathrm{Cu}, \mathrm{As}$, and Fe (Table 3), which was similar to the results of correlation analysis. $\mathrm{Cr}$ and $\mathrm{Mn}$ were included in the second principal component that explained $17.287 \%$ of total variance. Moreover, Cd might negatively contribute to the second principal component. The third principal component was only composed of $\mathrm{Zn}$, accounting for $11.565 \%$ of the total variance (Table 3). Elements $\mathrm{Co}, \mathrm{Ni}, \mathrm{Cu}, \mathrm{As}$, and Fe might originate from the seepage of industrial and mining wastewater as well as saline water intrusion. $\mathrm{Cr}$ and $\mathrm{Mn}$ might mainly come from the industrial activities. $\mathrm{Zn}$
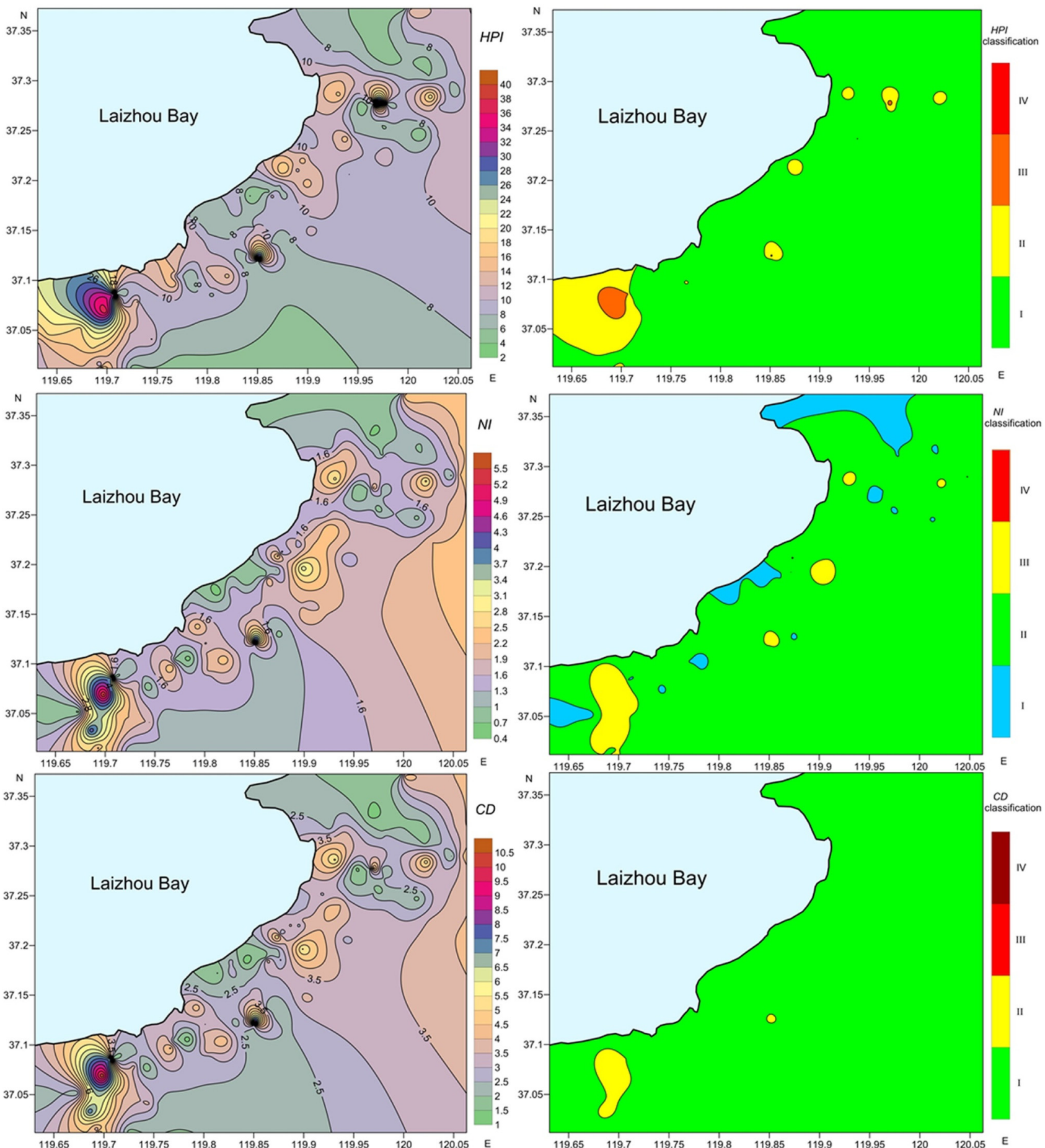

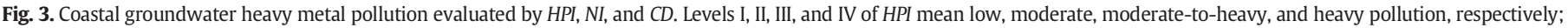

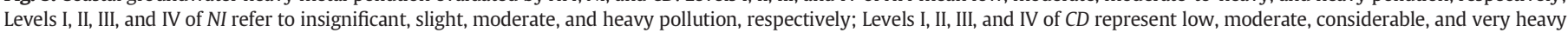
pollution, respectively. 
might originate from feces and usage of fertilizers and pesticides. $\mathrm{Cd}$ and $\mathrm{Pb}$ might be influence by mixed sources. Therefore, heavy metals in groundwater might mainly originate from anthropogenic activities and saline water intrusion.

\subsection{Pollution of heavy metals in the coastal groundwater}

Except Fe, the concentrations of the remaining heavy metals in groundwater were generally below the Class III thresholds. However, more information on the comprehensive pollution caused by all heavy metals in groundwater was needed to provide the basis for the environmental management in this region. Therefore, pollution of all target heavy metals in groundwater of southern Laizhou Bay was determined by three methods including $H P I, N I$, and $C D$ (Fig. 3). HPI values of all sampling sites ranged from 3.92 (GW25) to 38.34 (GW38) with the average of 10.66. Based on the HPI ranking criteria, approximately 98,11 , and 4 sampling sites showed low, moderate, and moderate-to-high groundwater pollution by heavy metals, respectively. Moderate and moderate-tohigh heavy metal pollution mainly occurred in the southwestern region of the study area (Fig. 3), which was identical with the regions where the highest concentrations of $\mathrm{As}, \mathrm{Co}, \mathrm{Cu}, \mathrm{Fe}$, and $\mathrm{Ni}$ occurred. Elements including $\mathrm{Ni}$, As, Fe, and $\mathrm{Pb}$ were the main contributors for pollution, averagely accounting for $90.99 \%$ of heavy metal pollution. NI values were in the range of 0.54 (GW70)-5.55 (GW107) with the average of 1.63. Approximately $19.47 \%, 71.68 \%$, and $8.85 \%$ of sampling sites showed slight, low, and moderate heavy metal pollution, respectively. Moderate pollution mainly occurred in the southwestern and central regions of the study area (Fig. 3). In general, pollution evaluated by HPI was more serious than that assessed by NI. Fe was the dominant contributor for pollution evaluated by NI. CD values of the sampling sites ranged from 1.20 (GW7) to 10.40 (GW107) with the average of 3.08. Approximately 109 and 4 sampling sites were endured low and moderate pollution, respectively. Moderate pollution mainly occurred in the southwestern and central regions of the study area (Fig. 3). Pollution assessed by NI was generally more serious than that evaluated by $C D$. Similar to NI results, Fe was also the dominant contributor for pollution evaluated by $C D$.

According to the "worst-scenario", approximately $86.73 \%$ and $13.27 \%$ of sampling sites showed low and moderate or higher

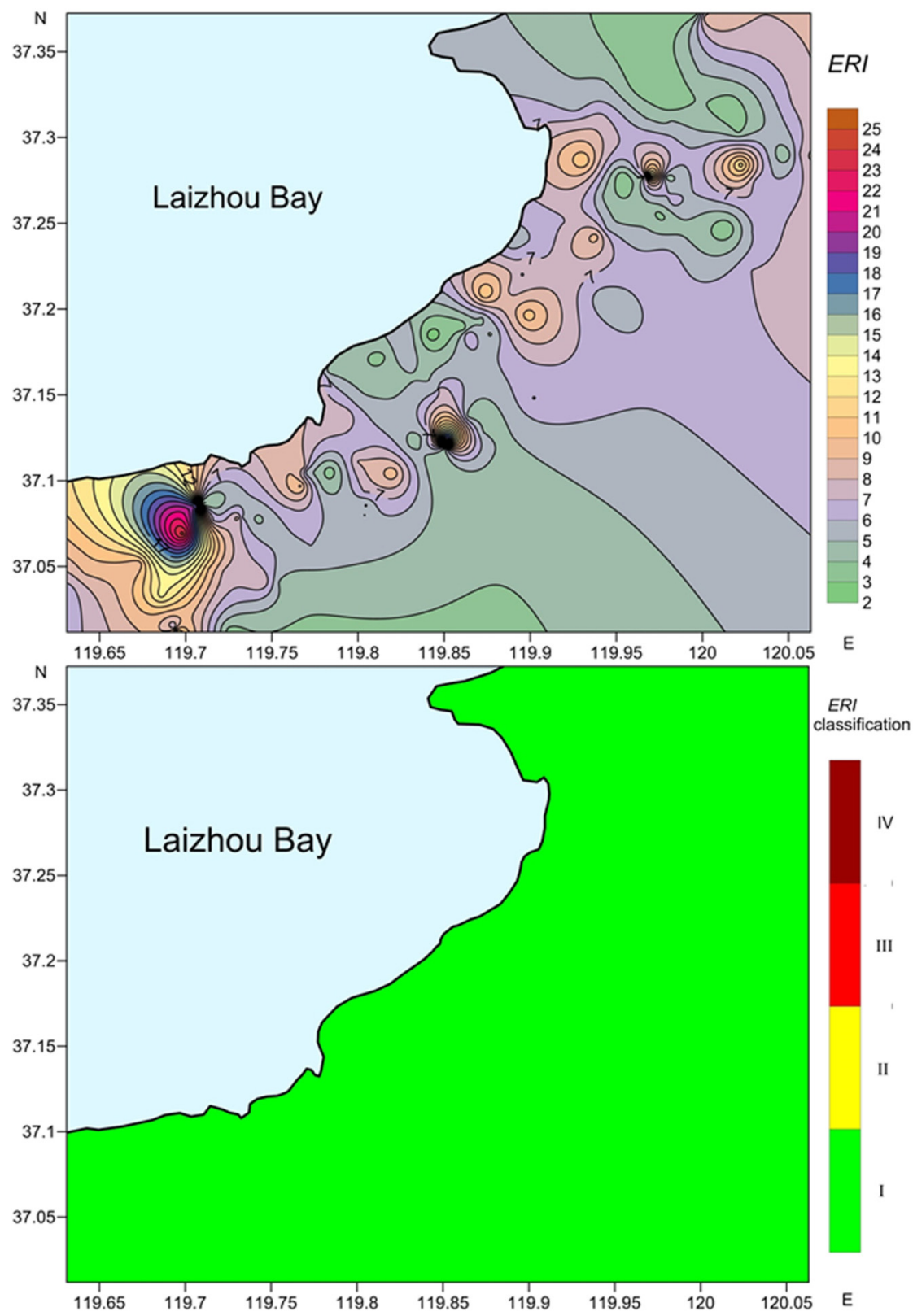

Fig. 4. Ecological risks posed by heavy metals in coastal groundwater. Levels I, II, III, and IV refer to low, moderate, considerable, and very heavy ecological risk, respectively. 

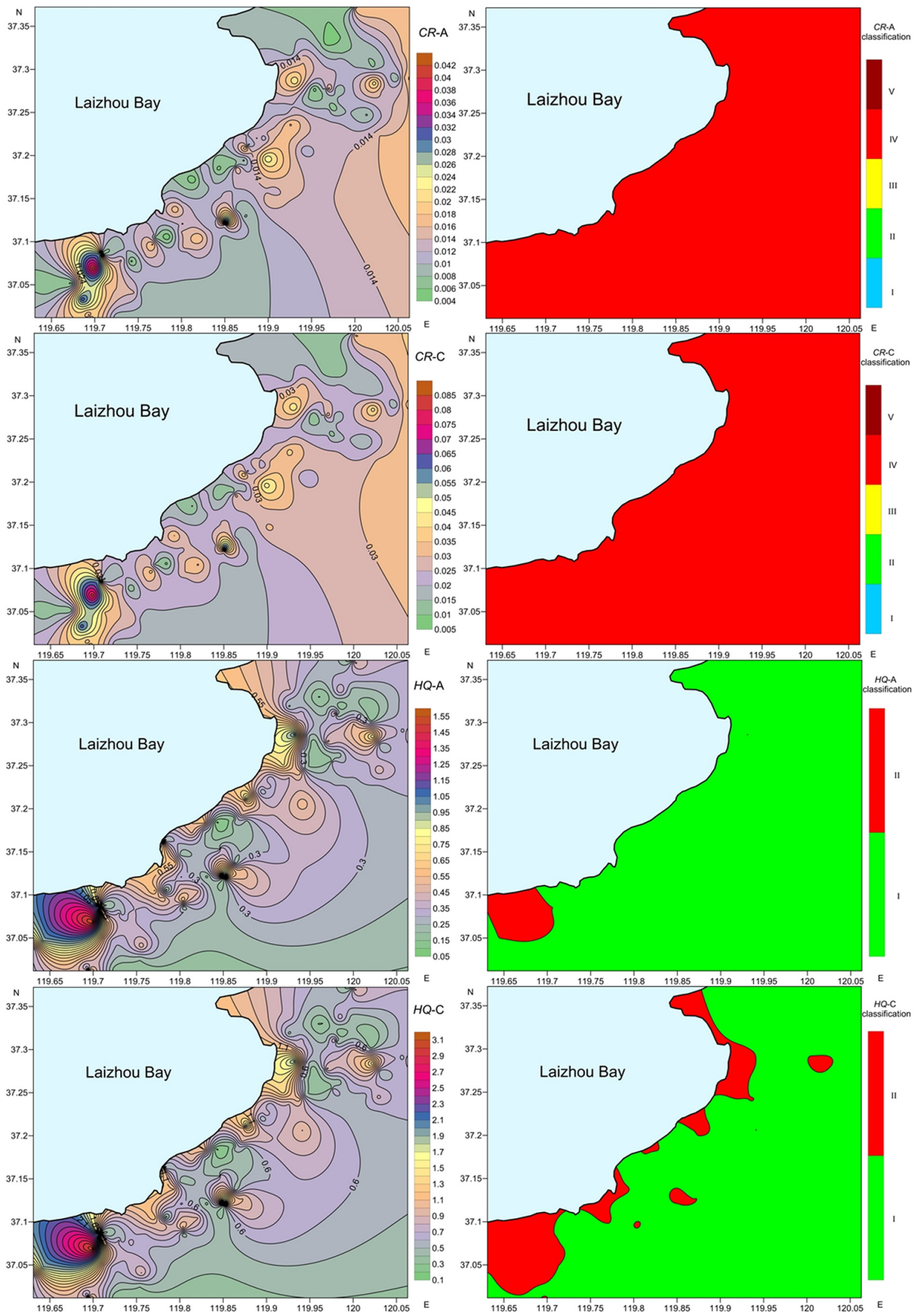

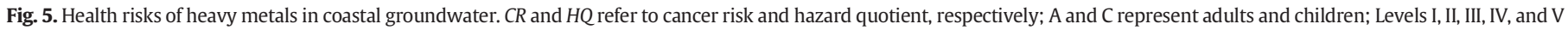
for $C R$ refer to very low, low, moderate, high, and very heavy cancer risks, respectively; Levels I and II for $H Q$ mean acceptable and unacceptable non-cancer risks, respectively. 
groundwater heavy metal pollution, respectively. Moreover, relatively high $H P I, N I$, and $C D$ values were found in the southwestern coast of the study area where severe groundwater salinization occurred, indicating that coastal groundwater salinization could lead to the increase in the pollution of heavy metals in the coastal aquifers. Considering that all water samples were collected from the drinking wells, groundwater pollution needs more attention and effective control.

\subsection{Ecological risks posed by heavy metals in the coastal groundwater}

Potential ecological risks of heavy metals in groundwater of the study area were evaluated using ERI model. ERI values ranged from 2.45 to 24.39 , which suggested that heavy metals exerted low ecological risks to groundwater systems of all sites (Fig. 4). The ERI values of southwestern coast of the study area where severe groundwater salinization occurred were much higher than those of other areas, indicating that the salinization led to the increase in the ecological risks in the coastal groundwater. Fe was the dominant risk contributor with the contribution percentage ranging from $9.23 \%$ to $44.37 \%$ and the average percentage of $34.67 \%$. Ni was the second risk contributor with contribution percentage in the range of $6.12 \%-43.44 \%$ and the mean value of $29.41 \%$. Metalloid As averagely contributed to approximately $22.04 \%$ of ecological risks. $\mathrm{Cu}$ and $\mathrm{Mn}$ were the weakest risk contributors with the average contribution percentages of $0.09 \%$ and $0.18 \%$, respectively. Therefore, effective control of $\mathrm{Fe}, \mathrm{Ni}$, and As in groundwater will significantly decrease the potential ecological risks posed by heavy metals in groundwater of the study area.

\subsection{Health risks posed by heavy metals in the coastal groundwater}

Health risks of heavy metals in groundwater were evaluated by cancer risks and hazard quotients through ingestion (drinking water) and dermal contact pathways. Cancer risks and hazard quotients of heavy metals for adults and children were illustrated by Fig. 5. Both the cancer risks and hazard quotients of heavy metals in southwestern coastal groundwater of the study area where severe groundwater salinization occurred were much higher than those of the remaining areas, indicating that the salinization led to the increase in the health risks in the coastal groundwater.

Cancer risks of heavy metals in groundwater for adults varied from $4.39 \times 10^{-3}$ to $4.15 \times 10^{-2}$ with the mean value of $1.25 \times 10^{-2}$ while those for children ranged from $8.79 \times 10^{-3}$ to $8.32 \times 10^{-2}$ with the average of $2.50 \times 10^{-2}$. Cancer risks of heavy metals for children were generally twice for adults. Cancer risks through ingestion pathway accounted for about $98.92 \%-99.91 \%$ and $98.09 \%-99.84 \%$ of total risks for adults and children, respectively. Cancer risks for both adults and children were classified into high levels at all sampling sites. Fe was the dominant contributor for cancer risks through ingestion and dermal contact pathways. $\mathrm{Cr}$ and $\mathrm{Ni}$ also contributed to cancer risks through dermal contact to some extent.

Hazard quotients of heavy metals in groundwater for adults ranged from $9.58 \times 10^{-2}$ to 1.55 with the mean value of $3.95 \times 10^{-1}$ while those for children varied from $1.91 \times 10^{-1}$ to 3.07 with the average of $7.72 \times 10^{-1}$. Hazard quotients of heavy metals for children were generally 1.96 times those for adults. Hazard quotients through ingestion accounted for approximately $78.98 \%-99.66 \%$ of total non-cancer risks for adults while those accounted for $85.06 \%-99.78 \%$ of total risks for children. Non-cancer risks for adults were acceptable at 108 sampling sites and unacceptable at 5 sites. Non-cancer risks for children were classified into unacceptable at 20 sampling sites and acceptable at 93 sites. Metalloid As was the dominant contributor for hazard quotients through ingestion, and followed by $\mathrm{Co}, \mathrm{Fe}, \mathrm{Ni}$, and $\mathrm{Cr}$. Fe was the dominant contributor for non-cancer risks through dermal contact, and followed by $\mathrm{Cr}$ and $\mathrm{Ni}$.

\section{Conclusions}

The investigation provided initial and important information on heavy metals pollution in coastal aquifer with saline water intrusion. The heavy metal pollution in the coastal groundwater of Laizhou Bay was mainly caused by anthropogenic activities and groundwater salinization according to PCA analysis. Fe was the dominant heavy metal in groundwater with the maximal and average concentrations reaching 2333.76 and $686.92 \mu \mathrm{g} / \mathrm{L}$, respectively. Concentrations of Fe in groundwater exceeded Class III threshold $(300 \mu \mathrm{g} / \mathrm{L})$ at $98.23 \%$ of sampling sites. Approximately $86.73 \%$ and $13.27 \%$ of sampling sites showed low and moderate or higher groundwater heavy metal pollution based on HPI evaluation. ERI values ranged from 2.45 to 24.39, which suggested that heavy metals exerted low ecological risks to groundwater systems of all sites. Cancer risks for both adults and children were classified into high levels at all sampling sites. Non-cancer risks for adults were unacceptable at $4.42 \%$ of sampling sites while those for children were unacceptable at $17.70 \%$ of sampling sites. Effective control of heavy metals in coastal groundwater of Laizhou Bay is needed. The southwestern coastal plains of the study area showed significant groundwater salinization trend. The salinization of the coastal groundwater could lead to the increase in the heavy metal pollution and ecological-health risks in coastal groundwater.

\section{Acknowledgements}

This work was supported by National Natural Science Foundation of China (Nos. 41671319 and 41877131), One Hundred Talents Program of Chinese Academy of Sciences (Grant numbers of Y629041021 and Y610061033), CAS “Light of West China Program”, Key Research Program of Frontier Sciences of CAS (Grant No. QYZDJ-SSW-DQC015), Two-Hundred Talents Plan of Yantai (Y739011021), and Thousand Talents Plan of Qinghai Province (Y740171071). The authors would like to thank the reviewers for their valuable suggestions and comments on the manuscript.

\section{Appendix A. Supplementary data}

Supplementary data to this article can be found online at https://doi. org/10.1016/j.scitotenv.2018.10.250.

\section{References}

Acosta, J.A., Jansen, B., Kalbitz, K., Faz, A., Martínez-Martínez, S., 2011. Salinity increases mobility of heavy metals in soils. Chemosphere 85, 1318-1324.

Ağca, N., Karanlık, S., Ödemis, B., 2014. Assessment of ammonium, nitrate, phosphate, and heavy metal pollution in groundwater from Amik Plain, southern Turkey. Environ. Monit. Assess. 186, 5921-5934.

Akhbarizadeh, R., Moore, F., Keshavarzi, B., Moeinpour, A., 2016. Aliphatic and polycyclic aromatic hydrocarbons risk assessment in coastal water and sediments of Khark Island, SW Iran. Mar. Pollut. Bull. 108, 33-45.

Basahi, J.M., Masoud, M.H.Z., Rajmohan, N., 2018. Effect of flash flood on trace metal pollution in the groundwater - Wadi Baysh Basin, western Saudi Arabia. J. Afr. Earth Sci. 147, 338-351.

Béjar-Pizarro, M., Ezquerro, P., Herrera, G., Tomás, R., Guardiola-Albert, C., Ruiz Hernández, J.M., Fernández Merodo, J.A., Marchamalo, M., Martínez, R., 2017. Mapping groundwater level and aquifer storage variations from InSAR measurements in the Madrid aquifer, Central Spain. J. Hydrol. 547, 678-689.

Bricker, S.H., Banks, V.J., Galik, G., Tapete, D., Jones, R., 2017. Accounting for groundwater in future city visions. Land Use Policy 69, 618-630.

Burges, A., Epelde, L., Garbisu, C., 2015. Impact of repeated single-metal and multimetal pollution events on soil quality. Chemosphere 120, 8-15.

Chaturvedi, A., Bhattacharjee, S., Singh, A.K., Kumar, V., 2018. A new approach for indexing groundwater heavy metal pollution. Ecol. Indic. 87, 323-331.

Du, Y., Ma, T., Chen, L., Shan, H., Xiao, C., Lu, Y., Liu, C., Cai, H., 2015. Genesis of salinized groundwater in Quaternary aquifer system of coastal plain, Laizhou Bay, China: geochemical evidences, especially from bromine stable isotope. Appl. Geochem. 59, $155-165$.

Edet, A.E., Offiong, O.E., 2002. Evaluation of water quality pollution indices for heavy metal contamination monitoring. A study case from Akpabuyo-Odukpani area, Lower Cross River Basin (southeastern Nigeria). GeoJournal 57, 295-304. 
Eschauzier, C., Raat, K.J., Stuyfzand, P.J., De Voogt, P., 2013. Perfluorinated alkylated acids in groundwater and drinking water: identification, origin and mobility. Sci. Total Environ. 458-460, 477-485.

Fram, M.S., Belitz, K., 2011. Occurrence and concentrations of pharmaceutical compounds in groundwater used for public drinking-water supply in California. Sci. Total Environ. 409, 3409-3417.

Ge, J., Woodward, L.A., Li, Q.X., Wang, J., 2013. Composition, distribution and risk assessment of organochlorine pesticides in soils from the Midway Atoll, North Pacific Ocean. Sci. Total Environ. 452-453, 421-426.

Gholami, V., Chau, K.W., Fadaee, F., Torkaman, J., Ghaffari, A., 2015. Modeling of groundwater level fluctuations using dendrochronology in alluvial aquifers. J. Hydrol. 529, 1060-1069.

Hakanson, L., 1980. An ecological risk index for aquatic pollution control, a sedimentological approach. Water Res. 14, 975-1001.

Han, D.M., Song, X.F., Currell, M.J., Yang, J.L., Xiao, G.Q., 2014. Chemical and isotopic constraints on evolution of groundwater salinization in the coastal plain aquifer of Laizhou Bay, China. J. Hydrol. 508, 12-27.

IRIS (Integrated Risk Information System by United States Environmental Protection Agency), 2018. https://cfpub.epa.gov/ncea/iris/search/index.cfm?first letter $=$ C, Accessed date: 6 June 2018.

Kampouroglou, E.E., Economou-Eliopoulos, M., 2017. Assessment of arsenic and associated metals in the soil-plant-water system in Neogene basins of Attica, Greece. Catena 150, 206-222.

Li, Z., Wang, G., Wang, X., Wan, L., Shi, Z., Wanke, H., Uugulu, S., Uahengo, C.-I., 2018. Groundwater quality and associated hydrogeochemical processes in Northwest Namibia. J. Geochem. Explor. 186, 202-214.

Liu, S., Zhang, Y., Bi, S., Zhang, X., Li, X., Lin, M., Hu, G., 2015a. Heavy metals distribution and environmental quality assessment for sediments off the southern coast of the Shandong Peninsula, China. Mar. Pollut. Bull. 100, 483-488.

Liu, H., Hu, Y., Qi, S., Xing, X., Zhang, Y., Yang, D., Qu, C., 2015b. Organochlorine pesticide residues in surface water from Sichuan Basin to Aba Prefecture profile, east of the Tibetan Plateau. Front. Earth Sci. 9, 248-258.

Liu, S., Tang, Z., Gao, M., Hou, G., 2017. Evolutionary process of saline-water intrusion in Holocene and Late Pleistocene groundwater in southern Laizhou Bay. Sci. Total Environ. 607-608, 586-599.

Lu, S.G., Tang, C., Rengel, Z., 2004. Combined effects of waterlogging and salinity on electrochemistry, water-soluble cations and water dispersible clay in soils with various salinity levels. Plant Soil 264, 231-245.

Qu, L., Huang, H., Xia, F., Liu, Y., Dahlgren, R.A., Zhang, M., Mei, K., 2018. Risk analysis of heavy metal concentration in surface waters across the rural-urban interface of the Wen-Rui Tang River, China. Environ. Pollut. 237, 639-649.

Ranjbar Jafarabadi, A., Riyahi Bakhtiyari, A., Toosi, A.S., Jadot, C., 2017. Spatial distribution, ecological and health risk assessment of heavy metals in marine surface sediments and coastal seawaters of fringing coral reefs of the Persian Gulf, Iran. Chemosphere 185, 1090-1111.

Santucci, L., Carol, E., Tanjal, C., 2018. Industrial waste as a source of surface and groundwater pollution for more than half a century in a sector of the Río de la Plata coastal plain (Argentina). Chemosphere 206, 727-735.

Sarria-Villa, R., Ocampo-Duque, W., Páez, M., Schuhmacher, M., 2016. Presence of PAHs in water and sediments of the Colombian Cauca River during heavy rain episodes, and implications for risk assessment. Sci. Total Environ. 540, 455-465.
Sefelnasr, A., Gossel, W., Wycisk, P., 2015. Groundwater management options in an arid environment: the Nubian Sandstone Aquifer System, Eastern Sahara. J. Arid Environ. $122,46-58$

Sharifi, Z., Hossaini, S.M.T., Renella, G., 2016. Risk assessment for sediment and stream water polluted by heavy metals released by a municipal solid waste composting plant. J. Geochem. Explor. 169, 202-210.

Stumm, W., 1992. Chemistry of the Solid-water Interface: Processes at the Mineral-water and Particle-water Interface in Natural Systems. John Wiley \& Sons, Inc., New York, United States.

Szekeres, E., Chiriac, C.M., Baricz, A., Szőke-Nagy, T., Lung, I., Soran, M.-L., Rudi, K., Dragos, N., Coman, C., 2018. Investigating antibiotics, antibiotic resistance genes, and microbial contaminants in groundwater in relation to the proximity of urban areas. Environ. Pollut. 236, 734-744.

Tam, V.T., Batelaan, O., Le, T.T., Nhan, P.Q., 2014. Three-dimensional hydrostratigraphical modelling to support evaluation of recharge and saltwater intrusion in a coastal groundwater system in Vietnam. Hydrogeol. J. 22, 1749-1762.

USEPA (U.S. Environmental Protection Agency), 2004. Risk Assessment Guidance for Superfund Volume I: Human Health Evaluation Manual (Part E, Supplemental Guidance for Dermal Risk Assessment). Office of Superfund Remediation and Technology Innovation, Washington, DC

USEPA (U.S. Environmental Protection Agency), 2016. Regional Screening Levels (RSLs) user's guide. available on. https://www.epa.gov/risk/regional-screening-levels-rslsusers-guide-may-2016.

Vandenbohede, A., Van Houtte, E., Lebbe, L., 2009. Sustainable groundwater extraction in coastal areas: a Belgian example. Environ. Geol. 57, 735-747.

Vu, C.T., Lin, C., Shern, C.-C., Yeh, G., Le, V.G., Tran, H.T., 2017. Contamination, ecological risk and source apportionment of heavy metals in sediments and water of a contaminated river in Taiwan. Ecol. Indic. 82, 32-42.

Wen, X., Feng, Q., Lu, J., Wu, J., Wu, M., Guo, X., 2018. Risk assessment and source identification of coastal groundwater nitrate in northern China using dual nitrate isotopes combined with Bayesian mixing model. Hum. Ecol. Risk. Assess. 24, 1043-1057.

WHO (World Health Organization), 2017. Guidelines for drinking-water quality. 4th edition. (incorporating the 1st addendum).

Wu, J., Lu, J., Luo, Y., Duan, D., Zhang, Z., Wen, X., Min, X., Guo, X., Boman, B.J., 2016. An overview on the organic pollution around the Qinghai-Tibet plateau: the thoughtprovoking situation. Environ. Int. 97, 264-272.

Wu, J., Zhao, W., Lu, J., Jin, S., Wang, J., Qian, J., 2018a. Geographic information system based approach for the investigation of groundwater nitrogen pollution near a closed old landfill site in Beijing, China. Environ. Eng. Manag. J. 17, 1095-1101.

Wu, J., Lu, J., Li, L., Min, X., Luo, Y., 2018b. Pollution, ecological-health risks, and sources of heavy metals in soil of the northeastern Qinghai-Tibet Plateau. Chemosphere 201, 234-242.

Zhang, Y., Li, H., Wang, X., Zheng, C., Wang, C., Xiao, K., Wan, L., Wang, X., Jiang, X., Guo, H., 2016. Estimation of submarine groundwater discharge and associated nutrient fluxes in eastern Laizhou Bay, China using ${ }^{222} \mathrm{Rn}$. J. Hydrol. 533, 103-113.

Zhu, L., Gong, H., Li, X., Wang, R., Chen, B., Dai, Z., Teatini, P., 2015. Land subsidence due to groundwater withdrawal in the northern Beijing plain, China. Eng. Geol. 193, 243-255. 